\section{ADMINISTRASI LAYANAN KHUSUS}

\section{BAB I PENDAHULUAN}

Administrasi layanan khusus adalah memberi layanan secara khusus atau suatu usaha yang tidak secara langsung berkenaan dengan proses belajar mengajar di kelas. Tetapi secara khusus diberikan oleh sekolah kepada para siswamnya agar mereka lebih optimal dalam melaksanakan proses belajar.Manajemen layanan khusus di suatu sekolah merupakan bagian penting dalam Manajemen Berbasis Sekolah (MBS) yang efektif dan efisien.Sekolah merupakan salah satu sarana yang dapat digunakan untuk meningkatkan kualitas dari penduduk bangsa Indonesia. Hal ini sesuai dengan UU No. 19 Tahun 2005 tentang Standar Nasional Pendidikan Bab II Pasal 4 yang memuat tentang adanya tujuan pendidikan nasional.

\section{BAB II METODOLOGI PENELITIAN}

Artikel ilmiah hendaknya disusun dengan metode dan langkah-langkah yang sistematis untuk memudahkan melakukan penelitian. Pada artikel ini, peneliti menggunakan metode studi literatur dengan cara mengumpulkan literature (bahan-bahan materi) yang bersumber dari buku, jurnal, dan sumber lainnya terkait ilmu tentang Administrasi Pendidikan. Berisi abstrak yang menerangkan ringkasan dan tujuan artikel, serta keyword untuk memudahkan pembaca dalam mencari kata kunci, beserta pendahuluan latar belakang artikel dan metode penelitian artikel serta inti dari isi artikel dan kesimpulan serta daftar pustaka.Disini penulis mengambil bahan berdasarkan sumber terpecaya artikel (Hadeafriansyah 2019).

\section{BAB III KAJIAN TEORI DAN PEMBAHASAN}

1.Pengertian administrasi layanan khusus

Untuk memenuhi tugas dan tanggung jawab tersebut maka sekolah memerlukan suatu manajemen layanan khusus yang dapat mengatur segala kebutuhan peserta didiknya sehingga tujuan pendidikan tersebut dapat tercapai.Dari uraian tersebut dapat disimpulkan bahwa manajemen layanan khusus adalah suatu proses kegiatan memberikan pelayanan kebutuhan 
kepada peserta didik untuk menunjang kegiatan pembelajaran agar tujuan pendidikan bisa tercapai secara efektif dan efisien.

2.Jenis-Jenis Layanan Khusus dan Pengelolahannya

Pelayanan khusus yang diberikan sekolah kepada peserta didik, antar sekolah satu dengan sekolah lainnya pada umumnya sama, tetapi proses pengelolan dan pemanfaatannya yang berbeda. Beberapa bentuk layanan khusus yang ada di sekolah antara lain yaitu:

\section{a) Pustaka}

Perpustakaan merupakan salah satu unit yang memberikan layanan kepada peserta didik, dengan maksud membantu dan menunjang proses pembelajaran di sekolah, melayani informasi-informasi yang dibutuhkan serta memberi layanan rekreatif melalui koleksi bahan pustaka.Menurut Supriyadi (1983) dalam buku Manajemen Peserta Didik oleh Ali Imron mendefinisikan perpustakaan sekolah sebagai perpustakaan yang diselenggarakan di sekolah guna menunjang program belajar mengajar di lembaga pendidikan formal seperti sekolah, baik sekolah tingkat dasar maupun menengah, baik sekolah umum maupun kejuruan. Perpustakaan sekolah adalah perpustakaan yang tergabung pada sebuah sekolah, dikelola sepenuhnya oleh sekolah yang bersangkutan, dengan tujuan utama membantu sekolah untuk mencapai tujuan khusus sekolah dan tujuan pendinikan pada umumnya. Ada beberapa jenis perpustakaan sekolah, yang pada dasarnya disesuaikan dengan jenjang atau tingkat sekolah yang bersangkutan. Jenis perpustakaan sekolah tersebut adalah perpustakaan taman kanak-kanak, perpustakaan sekolah dasar, perpustakaan sekolah lanjutan tingkat pertama dan perpustakaan sekolah lanjutan tingkat atas. Semua jenis perpustakaan sekolah yang disebutkan diatas dikelola berdasarkan tujuan khusus masingmasing jenis dan jenjang sekolah.

Fungsi perpustakaan sekolah adalah:

a. fungsi pendidikan

b. fungsi informasi 
c. fungsi rekreasi

d. fungsi penelitian

e. fungsi penyaluran hobi

f. fungsi penanaman rasa tanggung jawab

Pengelolaan bahan pustaka

Sebelum bahan pustaka dapat dipinjamkan kepada pengunjung bahan tersebut harus diolah terlebih dahulu. Proses pengolahan bahan pustaka tersebut melalui tahap-tahap berikut:

a. Klasifikasi

b. Katalogisasi

c. Pemberian stempel

d. Pemberian nomor buku

e. Pengaturan buku dirak

c) Peranan guru dalam administrasi perpustakaan sekolah

Ada beberapa peranan guru yang terlibat dalam administrasi perpustakaan sekolah. Peran tersebut antara lain:

a. Memperkenalkan buku-buku kepada siswa dan guru-guru

b. Memilih buku-buku dan bahan pustaka lainnya yang kan dibeli

c. Mempromosikan perpustakaan baik untuk pemakaian, maupun pembinaanya

d. Mengetahui jenis dan menguasai criteria-krikteria umum yang menentukan baik buruknya susu koleksi

e. Mengusahakan agar siswa aktif membantu perkembangan perpustakaan

b) Labor

Labolatorium secara sederhana dapat diuraikan sebagai suatu tempat dimana dosen, mahasiswa, guru, siswa, dan orang lain melaksanakan kegiatan kerja ilmiah seperti pratikum, observasi, penelitian, demokrasi dan pembuatan model-model dalam rangka kegiatan belajar mengajar.

$$
\text { * Jenis-jenis laboratorium }
$$

labolatorium dapat dibedakan atas berapa jenis' jenis-jenis laboratorium tersebut biasanya disesuaikan dengan bidang studi atau kelompok bidang studi tertentu. Jenis laboratotium tersebut antra lain:

a. Menurut bidang studi misalnya: labolatorium kimia, fisika, pmp dan sebagainya

b. Menurut kelompok bidang studi 
misalnya : laboratorim IPS, IPA

c. Untuk bidang ilmu teknik labor dapat diartikan sebagai workshop/ bengkel kerja

langkah-langkah yang perlu diperhatikan dalam perencanaan penggunaan labor adalah:

a.Menganalisis kurikulum secara keseluruhan

b.Penentuan bobot taksonomik pokok bahasab

c. Pengembangan desain intruksional

d. Pengembangan materi dan pokok bahasan

e. Menetapkan apakah seluruh bagian, satu atau dua materi pokok bahasan yang memerlukan " labotory work"

f. Peralatan yang akan digunakan

g. Penetapan langkah-langkah dalam pengajaran dengan memakai laboratorium

c) UKS (Usaha Kesehatan Sekolah)

Usaha Kesehatan Sekolah merupakan salah satu wahana untuk meningkatkan kemampuan hidup sehat yang pada gilirannya menghasilkan derajat kesehatan peserta didik yang optimal. Usaha kesehatan sekolah tersebut bukan saja menjadi tanggung jawab pemerintah akan tetapi tanggung jawab peserta didik dan masyarakat dimana sekolah itu berada. Menurut Jesse Ferring William pada buku Pengelolaan Layanan Khusus $\mathrm{Di}$ sekolah oleh Kusmintardjo (1992) mendefinisikan layanan kesehatan adalah sebuah klinik yang didirikan sebagai bagian dari Universitas atau sekolah yang berdiri sendiri yang menentukan diagnosa dan pengobatan fisik dan penyakit jiwa dan dibiayai dari biaya khusus dari semua siswa. Selain itu layanan kesehatan juga dapat diartikan sebagai usaha sekolah dalam rangka membantu (mungkin bersifat sementara) murid-muridnya yang mengalami persoalan yang berkaitan dengan kesehatan.

Dengan demikian dapatlah dikatakan bahwa layanan kesehatan peserta didik adalah suatu layanan kesehatan masyarakat yang dijalankan di sekolah dan menjadikan peserta didik sebagai sasaran utama, dan personalia sekolah yang lainnya sebagai sasaran tambahan (Imron, 1995:154).

\section{Tujuan kesehatan sekolah}

Tujuan khusus usaha kesehatan sekolah adalah agar siswa:

a. Memiliki pengetahuan, sikap dan 
keterampilan untuk melaksanakan prinsip hidup sehat serta berpartisipasi aktif didalam usaha peningkatan kesehatan disekolah, dirumah tangga maupun dilingkungan masyarakat.

b.Sehat dalam arti fisik mental maupun social.

c.Memiliki daya khayat dan daya tangkal terhadap pengaruh buruk, penyalahgunaan narkotika, obat dan bahan berbahaya, alcohol, rook, dan sebagainya.

d) Kafetaria Sekolah

Pertimbangan awal pendirian kafetaria/warung/kantin sekolah adalah bukan karena unsur bisnis semata, tanpa memperhitungkan aspek lain yang lebih penting. Keberadaan kafetaria/warung/kantin sekolah diharapkan mampu menyokong kelancaran proses belajar mengajar dari sisi keperluan akan makanan bagi siswa. Kafetaria/warung/kantin sekolah secara tidak langsung mempunyai kaitan dengan proses belajar-mengajar di sekolah. Adakalanya proses belaharmengajar tidak dapat berjalan sebagaimana mestinya karena siswa lapar dan haus.

Beberapa hal yang harus diperhatikan dalam administrasi kafetaria itu adalah:

a. Administrasi kafetaria/warung/kantin sekolah harus menjaga kesehatan (higienitas) masakan-masakan yang dijajakan kepada siswa.

b. Kebersihan tempat juga harus menjadi pertimbangan utama, karena kebersihan diharapkan dapat menjauhkan penyebaran hama penyakit.

c.Makanan-makanan yang disediakan hendaknya makanan yang bergizi tinggi, dan bilamana perlu dapat menambahkan vitamin-vitamin yang diperlukan siswa pada umumnya.

d.Harga makanan-makanan hendaknya dapat dijangkau atau sesuai dengan kondisi ekonomi siswa.

e.Usahakan agar kafetaria/warung/kantin sekolah tidak memberikan kesempatan kepada siswa untuk berlama-

lama atau nongkrong. Kondisi yang demikian akan menyokong munculnya perilaku-perilaku negatif. 


\section{e) Sarana Ibadah}

Di setiap sekolah, layanan rumah peribadatan sangat diperlukan. Layanan rumah peribadatan merupakan sebuah layanan yang diberikan sekolah dengan maksud agar layanan tersebut bisa digunakan untuk beribadah maupun melaksanakan kegiatan keagamaan lainnya, serta bisa membentuk kerohanian bagi peserta didik khususnya pada pihak sekolah lain pada umumnya. Agar bisa menjadi manusia yang baik dan beriman.

\section{* Asrama}

Bagi para peserta didik khususnya jenjang pendidikan menengah dan pendidikan tinggi, terutama bagi mereka yang jauh dari orang tuanya diperlukan diperlukan asrama.Selain manfaat untuk peserta didik, asrama mempunyai manfaat bagi para pendidik dan petugas asrama tersebut.

Layanan asrama sekolah sangat bermanfaat bagi peserta didik, diantaranya:

a. Tugas sekolah dapat dikerjakan dengan cepat dan sebaik-baiknya terutama jika berbentuk tugas kelompok. b. Sikap dan tingkah laku peserta didik dapat diawasi oleh petugas asrama dan para pendidik

c. Jika diantara peserta didik mengalami kesulitan (misalnya: kiriman orangtua terlambat), dapat saling membantu

d. Dapat meringankan kecemasan orangtua terhadap putra-putrinya

e. Merupakan salah ssatu cara untuk mengendalikan tingkah laku remaja yang kurang baik.

f) Koperasi

Koperasi berasal dari perkataan co dan operation, yang mengandung arti kerja sama untuk mencapi tujuan. Koperasi adalah "suatu perkumpulan yang beranggotakan orang-orang atau badan-badan, yang memberikan masuk dan keluar sebagai anggota; dengan bekerja sama secara kekeluargaan menjalankan usaha, untuk mempertinggi kesejahteraan jasmaniah para anggotanya". Tersebut mengandung unsur-unsur bahwa:

a. Perkumpulan koperasi bukan merupakan perkumpulan modal (bukan akumulasi modal), akan tetapi 
persekutuan sosial.

b. Sukarela untuk menjadi anggota, netral terhadap aliran dan agama.

c. Tujuannya mempertinggi kesejahteraan jasmaniah anggotaanggota dengan kerja sama secara kekeluargaan.

Layanan koperasi mendidik para peserta didik untuk dapat berwirausaha. Hal ini sangat membantu peserta didik di kehidupan yang akan datang. Koperasi sekolah adalah koperasi yang dikembangkan di sekolah, baik sekolah dasar, sekolah menengah, maupun sekolah dan dalam pengelolaannya melibatkan guru dan personalia sekolah.Sedangkan koperasi peserta didik atau biasa disebut disebut koperasi siswa (Kopsis) adalah koperasi yang ada di sekolah tetapi pengelolaanya adalah oleh pesera didik, kedudukan guru di dalam Kopsis adalah sebagai pembimbing saja.

\section{g) Transportasi}

Sarana transportasi bagi peserta didik merupakan sarana penunjang untuk kelancaran proses belajar mengajar. Peserta didik akan merasa aman dan dapat masuk atau pulang dengan waktu yang tepat. Transportasi yang diperlukan terutama bagi peserta didik ditingkat prasekolah dan sekolah dasar.Penyelenggara transportasi sebaiknya dilaksanakan oleh sekolah yang bersangkutan atau pihak swasta.

3. Peran Guru dalam Administrasi Layanan Khusus

a. Keterlibatan guru dalam administrasi perpustakaan misalnya memperkenalkan buku-buku kepada siswa.

b. Mengetahui jenis dan menguasai kriteria umum yang menentukan baik buruknya suatu koleksi buku-buku perpustakaan.

c. Mempromosikan perpustakaan baik pemakaian maupun untuk pembinaannya.

\section{BAB IV KESIMPULAN}

Administrasi layanan khusus adalah memberi layanan secara khusus atau suatu usaha yang tidak secara langsung berkenaan dengan proses belajar mengajar di kelas. Peran Guru dalam Administrasi Layanan Khusus yaitu 
keterlibatan guru dalam administrasi

perpustakaan misalnya

memperkenalkan buku-buku kepada

siswa dan mengetahui jenis dan

menguasai kriteria umum yang

menentukan baik buruknya suatu

koleksi buku-buku perpustakaan.

\section{DAFTAR PUSTAKA}

Afriansyah, H. (2019). Administrasi

layanan khusus. Padang. 